\title{
LITERASI DAN MODEL MANAJEMEN KEUANGAN UMKM BERBASIS DIGITAL PADA UMKM-UMKM DI KABUPATEN BOALEMO PROVINSI GORONTALO
}

\author{
Fibriyanti S. Lakoro $^{1)^{*}}$, Sukrianto ${ }^{2)}$. \\ ${ }^{1}$ Fakultas Ekonomi dan Bisnis, Universitas Bina Mandiri Gorontalo \\ email: fhee24@gmail.com \\ ${ }^{2}$ Fakultas Ekonomi dan Bisnis, Universitas Bina Mandiri Gorontalo \\ email: sukriyanto@ubmg.ac.id
}

\begin{abstract}
UMKM in Boalemo Regency have become a concern in recent times, especially in running their business. The purpose of the research is to provide knowledge to community groups/micro and small and medium enterprises (UMKM) about literacy and digital-based UMKM financial management models, and to be able to increase the participation of community groups/UMKM in managing UMKM through the provision of knowledge about digital-based management. Descriptive research method with a qualitative approach.The results showed that UMKM in Boalemo District experienced problems in running their businesses, especially during the pandemic due to the lack of government attention in helping UMKM in Boalemo District. The average UMKM in Boalemo Regency in the use of financial literacy fully understands the development of digital-based UMKM, especially in increasing income, even their education level in managing good financial management and digitally still relies on manual recording. While the digital-based UMKM financial management model is not in accordance with the targets and objectives. This is evidenced by UMKM business actors who have not been able to make financial reports. UMKM in Boalemo Regency have not been able to use information technology and social media, especially in utilizing digital based financial management designs. This is because UMKM only rely on manual recording.
\end{abstract}

Keywords: Literacy, Model, Financial Management and UMKM

\begin{abstract}
ABSTRAK
UMKM pada Kabupaten Boalemo memang menjadi perhatian dalam beberapa waktu terakhir terutama dalam menjalankan usahanya. Tujuan penelitian adalah untuk memberikan pengetahuan pada kelompok masyarakat/usaha mikro dan kecil menengah (UMKM) tentang literasi dan model manajemen keuangan UMKM berbasis digital, dan mampu meningkatkan partisipasi kelompok masyarakat/UMKM dalam pengelolaan UMKM melalui pemberian pengetahuan tentang pengelolaan berbasis digital. Metode penelitian deskriptif dengan pendekatan kualitatif. Hasil penelitian menunjukkan bahwa UMKM di Kabupaten Boalemo mengalami masalah dalam menjalankan usahanya terutama pada masa pandemi disebabkan karena kurangnya perhatian pemerintah dalam membantu UMKM yang ada di Kabupaten Boalemo. Rata-rata UMKM di Kabupaten Boalemo dalam penggunaan literasi keuangan sepenuhnya paham dalam pengembangan UMKM berbasis digital terutama dalam meningkatkan pendapatan, bahkan tingkat pendidikan mereka dalam mengelola manajemen keuangan yang baik serta secara digital masih mengandalkan pencatatan secara manual. Sedangkan model manajemen keuangan UMKM berbasis digital belum sesuai dengan target dan tujuan. Hal ini dibuktikan pelaku usaha UMKM belum mampu membuat laporan keuangan. UMKM di Kabupaten Boalemo belum mampu menggunakan teknologi informasi dan media sosial terutama dalam memanfaatkan desain model manajemen keuangan yang berbasis digital. Disebabkan para UMKM hanya mengandalkan pencatatan secara manual.
\end{abstract}

Kata Kunci: Literasi, Model, Manajemen Keuangan dan UMKM

*Corresponding author. E-mail: aldian@gmail.com 


\section{PENDAHULAN}

UMKM merupakan usaha yang produktif yang dimiliki perorangan atau badan usaha yang telah memenuhi kriteria sebagai usaha mikro. Dalam peraturan perundangundangan No. 20 tahun 2008, maka kriteria UMKM dibedakan secara masingmasing meliputi usaha mikro, usaha kecil, dan usaha menengah. Peluang terbesar dalam dunia digital seperti bisnis online ini sangatlah besar. UMKM mulai mengalami peningkatan secara pesat di dapat karna cepatnya penyebaran dan banyaknya jumlah orang yang melihat promosi kamu dalam pemasaran. Dengan strategi pemarasan online ini seseorang dapat menemukan produk-produk kita karena mereka membutuhkannya. Strategi pemasaran online ini juga bisa meningkatkan branding produk dan perusahaan kamu menjadi lebih terkesan profesional dan lebih kuat karena sudah tersebar kemana-mana.

Di Kabupaten Boalemo sendiri keadaan UMKM dari tahun 2015 sampai 2020 saat ini sudah mengalami pasang surut. Memulai dan mengoperasikan usaha mikro kecil menengah, mencakup kemungkinan keberhasilan sekaligus kegagalan. Karena ukurannya yang kecil, kesalahan manajemen sederhana cenderung mengarah pada kematian perusahaan kecil sehingga tidak ada kesempatan untuk belajar dari kesalahan masa lalunya. Belajar dari pengalaman masa lalu untu bermitra antara pengusaha kecil dan pengusaha besar harus diikat dengan peraturan formal, begitupun belum dapat berjalan dengan efektif sehingga tidak ada kesempatan untuk belajar dari kesalahan masa lalunya. Belajar dari pengalaman masa lalu untu bermitra antara pengusaha kecil dan pengusaha besar harus diikat dengan peraturan formal, begitupun belum dapat berjalan dengan efektif.

Hampir tiap tahunnya UMKM di Kabupaten Boalemo mengalami penurunan salah satu penyebab utamanya adalah UMKM belum bisa bertahan dengan modal yang dimiliki. Bahkan beberapa UMKM yang ditemui dilapangan Salah satu persoalan kenapa sampai hampir tiap tahunnya UMKM di Boalemo mengalami pasang surut disebabkan beberapa hal belum adanya modal, kualitas SDM, masih lemahnya jaringan usaha, bahkan mentalitas UKM, kurangnya transparansi, iklim usaha belum sepenuhnya kondusif, terbatasnya sarana dan prasarana usaha, bahkan pungutan liar. Bahkan beberapa UKM masih memiliki terbatasnya akses informasi.

Ditengah masa pandemi Corona Virus 19 atau Covid-19 yang paling terdampak padahal UMKM di Kabupaten Boalemo adalah terkait tenaga kerja. Resiko pailit yang sangat besar sehingga berpengaruh terhadap penurunan pendapatan bagi UMKM di Kabupaten Boalemo, hal ini disebabkan dari sisi pasokan dan permintaan serta adanya pembatasan pergerakan.

Seperti adanya pembatasan sosial berskala besar (PSBB). Bahkan bagi pelaku usaha UMKM di Kabupaten Boalemo adalah kesulitan mendapatkan bahan baku karena pemberlakuan kebijakan pembatasan sosial skala besar di beberapa daerah baik domestik maupun bahan baku impor karena pembatasan arus logistik. Permasalahan lainnya adalah permintaan terhadap produk yang berkurang, saat ini banyak orang yang akhirnya memilih untuk mengurangi konsumsi seperti belanja dan fokus ke kebutuhan sehari-hari saja sehingga membuat daya beli menjadi turun.

Bahkan dengan adanya penurunan permintaan terhadap barang yang membuat arus kas pelaku usaha di Boalemo menjadi tertekan sehingga menjadi masalah baru lagi bahkan pelaku ekonomi kreatif di Boalemo kesulitan melakukan pinjaman modal. Pemerintah 
saat ini menyiapkan program Pemulihan Ekonomi Nasional (PEN), termasuk untuk UMKM seperti penundaan dan subsidi bunga bagi UMKM yang mendapat kredit dari lembaga keuangan, penjaminan kredit model kerja baru, hingga penempatan dana di lembaga keuangan yang melakukan restrukturisasi kredit UMKM serta membantu mempromosikan UMKM baik secara lokal maupun global. Tujuan pelaksanaan penelitian adalah memberikan pengetahuan pada kelompok masyarakat/usaha mikro dan kecil menengah (UMKM) tentang literasi dan model manajemen keuangan UMKM berbasis digital, dan mampu meningkatkan partisipasi kelompok masyarakat/UMKM dalam pengelolaan UMKM melalui pemberian pengetahuan tentang pengelolaan berbasis digital

\section{KAJIAN LITERATUR}

\section{Literasi Keuangan}

Dalam Peraturan Otoritas Jasa Keuangan (OJK, 2016) adalah pengetahuan, keterampilan, dan keyakinan, yang mempengaruhi sikap dan perilaku untuk meningkatkan kualitas pengambilan keputusan dan pengelolaan keuangan dalam rangka mencapai kesejahteraan. Vidovicova (Wicaksono, 2015) menyebutkan bahwa Literasi keuangan merupakan pemahaman mengenai produk dan konsep keuangan dengan bantuan informasi dan saran, sebagai kemampuan untuk mengidentifikasi dan memahami risiko keuangan agar membuat keputusan keuangan yang tepat.

Begitupun Mandell (Wicaksono, 2015) mendefinisikan Literasi keuangan adalah kemampuan untuk mengevaluasi instrumen keuangan yang baru dan kompleks, serta dapat membuat penilaian pada instrumen keuangan. Menurut Lusardi (Aribawa, 2016) dalam mengatakan bahwa literasi keuangan terdiri dari sejumlah kemampuan dan pengetahuan mengenai keuangan yang dimiliki oleh seseorang untuk dapat mampu mengelola atau menggunakan sejumlah uang untuk meningkatkan taraf hidupnya. Literasi keuangan sebagai kemampuan dalam membaca, menganalisis, mengelola uang, dan berkomunikasi tentang pengalokasian sumber daya keuangan yang berpengaruh pada tingkat kesejahteraan dan proses pengambilan keputusan ekonomi yang tepat.(Shaari, 2013)

\section{Manajemen Keuangan}

Griffin (Ridhotullah, 2015) menyebutkan bahwa manajemen adalah sebuah proses perencanaan, pengorganisasian, pengoordinasian, dan pengontrolan sumber daya untuk mencapai sasaran secara efektif dan efisien. Menurut James C. Van Horne (Kasmir, 2012) mendefinisikan manajemen keuuangan atau pengelolaan keuangan adalah segala aktivitas yang berhubungan dengan perolehan, pendanaan, dan pengelolaan aktiva dengan beberapa tujuan menyeluruh. Sedangkan menurut Irawati (Mulyawan, 2015) mengatakan bahwa proses pengaturan aktivitas atau kegiatan keuangan dalam suatu organisasi yang didalamnya termasuk kegiatan planning, analisis, dan pengendalian terhadap keuangan. Bambang Riyanto (Mulyawan, 2015) mendefinisikan manajemen keuangan adalah keseluruhan dari aktivitas yang bersangkutan dengan usaha untuk mendapatkan dana

\section{Urgensi Usaha Kecil dan Menengah (UMKM)}

UMKM menurut Kementerian Koperasi dan UMKM dalam Aufar (2014:8) Usaha Kecil (UK), termasuk usaha Mikro (UMI) adalah entitas usaha yang mempunyai kekayaan bersih paling banyak Rp. 200.000.000, tidak termasuk tanah dan bangunan tempat usaha dan memiliki penjualan tahunan paling banyak $\mathrm{Rp}$. 1.000.000.000. Sementara itu, Usaha Menengah (UM) merupakan entitas usaha milik warga negara Indonesia yang 
memiliki kekayaan bersih lebih besar dari Rp. 200.000.000 s.d. Rp. 10.000.000 tidak termasuk tanah dan bangunan.Pentingnya UMKM ini juga telah diinformasikan dari berbagai sumber bahwa keberadaan Usaha Kecil dan Menengah (UMKM) sangat urgen karena dapat berkontribusi terhadap perluasan kesempatan kerja dan penyerapan tenaga kerja. Penyerapan tenaga kerja terbanyak yang mencapai 90 $\%$ berada pada usaha ini (BAPPENAS, 2017) Selain itu Bappenas menjelaskan bahwa UMKM memiliki peran penting dalam perekonomian masyarakat Indonesia karena terdapat tiga peran penting yang terkandung di dalamnya yaitu (1) Sarana mengentaskan masyarakat dari jurang kemiskinan, (2) Sarana untuk meratakan tingkat perekonomian rakyat kecil serta (3) memberikan pemasukan devisa bagi Negara. UKM atau yang biasa dikenal dengan usaha kecil menengah merupakan sebuah istilah yang mengacu pada suatu jenis usaha yang didirikan oleh pribadi dan memiliki kekayaan bersih paling banyak Rp 200.000.000,00 (belum termasuk tanah dan bangunan). (Nayla, 2014)

\section{UMKM Berbasis Digital}

(Hermann, M., Pentek, T., \& Otto, 2016) Ada empat model manajemen keuangan berbasis digital berdasarkan revolusi industri 4.0. Pertama, interkoneksi (sambungan) yaitu kemampuan mesin, perangkat, sensor, dan orang untuk terhubung dan berkomunikasi satu sama lain melalui Internet of Things (IoT) atau Internet of People (IoP). Prinsip ini membutuhkan kolaborasi, keamanan, dan standar. Kedua, transparansi informasi merupakan kemampuan sistem informasi untuk menciptakan salinan virtual dunia fisik dengan memperkaya model digital dengan data sensor termasuk analisis data dan penyediaan informasi. Ketiga, bantuan teknis yang meliputi : (a) kemampuan sistem bantuan untuk mendukung manusia dengan menggabungkan dan mengevaluasi informasi secara sadar untuk membuat keputusan yang tepat dan memecahkan masalah mendesak dalam waktu singkat, (b) kemampuan sistem untuk mendukung manusia dengan melakukan berbagai tugas yang tidak menyenangkan, terlalu melelahkan, atau tidak aman, (c) meliputi bantuan visual dan fisik. Keempat, keputusan terdesentralisasi yang merupakan kemampuan sistem fisik maya untuk membuat keputusan sendiri dan menjalankan tugas seefektif mungkin.

\section{Kerangka Pikir}

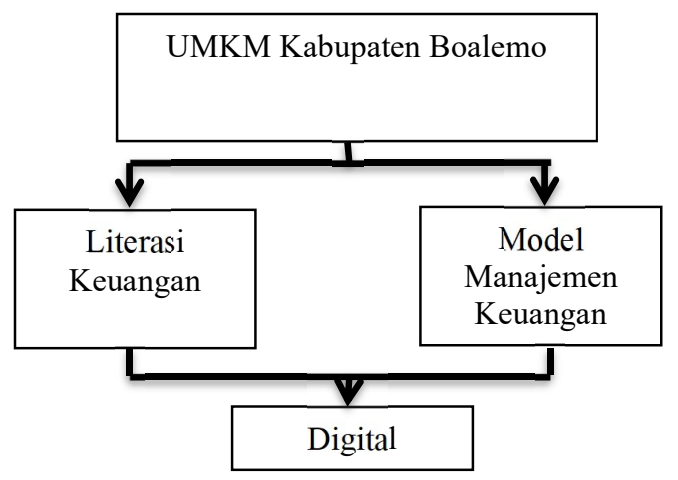

Gambar 1. Kerangka Penelitian

\section{METODE PENELITIAN}

Dalam penelitian ini menggunakan menggunakan metode penelitian kualitatif deskriptif. Penelitian kualitatif deskriptif (Sukmadinata, 2011) ditujukan untuk mendeskripsikan dan menggambarkan fenomena-fenomena yang ada, baik bersifat alamiah maupun rekayasa manusia, dengan memperhatikan mengenai karakteristik, kualitas, keterkaitan antar kegiatan. Penelitian kualitatif sebagai penelitian yang berlandaskan pada filsafat postpositivisme, digunakan dalam meneliti pada kondisi objek alamiah dengan teknik pengumpulan data triangulasi, analisis data bersifat induktif atau kualitatif, dan hasil penelitian kualitatif lebih menekankan makna daripada generalisasi. (Sugiyono, 2018) Lokasi penelitian dilaksanakan di UMKM-UMKM pada 6 Kecamatan di Kabupaten Boalemo, yaitu Tilamuta, Paguyaman Pantai, Mananggu, Botumoito, Paguyaman dan Dulupi. Jenis data yang 
digunakan dalam penelitian ini adalah kualitatif yang dimana dilakukan dengna menggunakan observasi, focus group discussion (FGD), wawancara mendalam (indepth interview) dan studi kasus (case study). Agara mampu menjawab pertanyaan dengan secara baik pada setiap lolkasi UMKM-UMKM di Kabupaten Boalemo maka perlu adanya informan yang terlibat secara langsung yaitu para pengelola/pemilik UMKM-UMKM. Sera Informan yang tidak terlibat secara langsung berupa pemerintah daerah, pemerintah desa dan lembaga keuangan.

Tujuan diadakannya focus group discussion (FGD) serta wawancara mendalam agar mampu menjawab akan permasalahan atau rumusan masalah yang akan dibahas. Setelah itu dilakukan maka peneliti akan melakukan analisis data dengan menggunakan model Miles (Sujarweni, 2014) dimana analisis ini dilakukan dengan melakukan pengumpulan data dilapangan dan setelah data terkumpul melakukan teknik analisis data model interaktif seperti reduksi data yang diperoleh ditulis dalam bentuk laporan atau data tabg terperinci dimana laporan yang ditulis berdasarkan data yang diperoleh direduksi, dirangkum, dipilih hal-hal yang penting. Kemudian dilakukan penyajian data dilakukan dengan mengkategorisasikan menurut pokok permasalahan yang akan dibuat dalam bentuk matriks atau dengan melihat penyajian-penyajian yang dilakukan dalam menganalisis tindakan berdasarkan pemahaman yang didapat. Penyimpulan dan verifikasi dilakukan sebagai tindak lanjut dari kegiatan reduksi data, penyajian data. Dimana kesimpulan akan diperoleh dengan melihat tahap awal biasanya data yang dinginkan kurang jelas dan memiliki dasar yang tegas. Maka dengan adanya kesimpulan akhir berdasarkan data sebelumnya maka akan menjawab masalah yang dinginkan

\section{HASIL DAN PEMBAHASAN}

Berdasarkan proses penelitian maka pada setiap sub bab yang dibahas akan dibahas mengenai hasil penelitian yang dijabarkan dan akan menjawab rumusan masalah yang dikemukan.

\section{HASIL PENELITIAN}

\section{Literasi Keuangan UMKM}

Berbicara terkait literasi keuangan pada umumnya membuat bingung para pelaku UMKM disebabkan keterbatasan pengetahuan seperti hasil wawancara dengan pemilik UMKM di Kecamatan Tilamuta mengatakan bahwa :

Untuk masalah literasi keuangan pada pengelolaan keuangan di UMKM kami memang masih membigungkan. Persoalan yang kami temui adalah seperti aplikasi atau sejenisnya. Rata-rata kami masih menggunakan pencatatan manual dan pelaporannya hanya menggunakan excel.

Literasi keuangan yang digunakan pada pelaku UMKM di Kabupaten Boalemo menganggap sulit dan masih bingung dalam menjalankannya. Seperti hasil waawancara dengan pelaku atau pemilik UMKM di Kecamatan Paguyaman Pantai mengatakan bahwa :

Pemahaman kami terkait literasi
keuangan dalam menjalankan
UMKM sangatlah
membingungkan. Bahkan dalam
hal pengelolaan UMKM kami
hanya mencatat sesuai kebuutuhan
seperti untung dan rugi dalam 1
bulan atau 1 tahun.

Tetapi ada beberapa pelaku UMKM pada Kecamatan Paguyaman dan Wonosari menjelaskan bahwa :

Cara pengelolaan keuangan pada UMKM menjadi salah satu 
kebutuhan kami dalam menjalankan dan memaksimalkan kebutuhan serta operasional UMKM. Karena kalau kami tidak mampu mengelola, mengatur, melaporkan dan menjalankan pengelolaan keuangan secara baik maka akan berakibat sangat buruk pada UMKM kami.

Persoalan yang ditemui memang bermacam-macam, terutama dalam mengaplikasikan literasi keuangan di UMKM Kabupaten Boalemo. Bahkan salah satu pemilik UMKM di Kecamatan Dulupi dan Pemiliki UMKM di Kecamatan Botumoito menjelaskan bahwa

Memang di UMKM kami sulit sekali memahami keuangan terutama dalam pencatatan, pelaporan, pengaplikasian. Dalam menjalankan UMKM kami sangat menyesuaikan pengelolaan keuangan yang kami jalankan agar mampu mengatur dan mengelola keuangan pada UMKM kami. Bahkan kelemahan terbesar pada usaha kami dalam mengelola keuangan adalah kurangnya SDM atau karyawan yang tidak mampu mengelola keuangan.

Berdasarkan penjelasan diatas terkait literasi keuangan yang dijalankan pada UMKM-UMKM di Kabupaten Boalemo Provinsi Gorontalo sepenuhnya belum mampu dilaksanakan. Karena melihat kondisi daerah, kondisi SDM dan UMKM sendiri yang memang dikatakan masih banyak yang belum paham.

\section{Model Manajemen Keuangan UMKM}

Model manajemen keuangan pada UMKM memang menjadi perhatian besar dalam pengelolaan keuangan. Hal ini disebabkan karena masih adanya model manajemen keuangan pada UMKM yang dikatakan masih ambigu atau dasar. Seperti hasil wawancara dengan pemilik UMKM pada
Kecamatan Dulupi, menjejelaskan bahawa

Kalau melihat dari model manajemen keuangan yang kami pakai, itu lebih banyak hanya mencatat pemasukan dan pengeluaran. Seperti diketahui pada pemasukan itu melihat dari banyaknya barang yang masuk atau terjual, kalau melihat barang yang terjual itu melihat dari kami belanja barang.

Hal yang sama diungkapkan pemilik UMKM di Kecamatan Wonosari dan Paguyaman, menjelaskan bahwa :

Untuk kondisi model manajemen keuangan yang digunakan memang sudah ada kami gunakan excel. Didalam pasti sudah dilakukan pengecekan barang, harga barang serta kegaitan keuangan lainnya. Sehingga model yang kami gunakan yaitu memakai excel. Sehingga lebih praktis dan lebih efektif dan efisien. Bahkan dalam mencari kekosongan barang dapat dnegan mudah kami pakai.

Memang model manajemen keuangan pada UMKM sudah ada variasi dan bentuknya sesuai dengan kebutuhan UMKM. Tetapi belum semua UMKM paham akan model manajemen keuangan UMKM yang dijalankan. Seperti hasil wawancara dengan pelaku atau pemilik UMKM di Kecamatan Tilamuta dan Botumoito mengatakan bahwa :

Pada UMKM kami memang sudah ada model manajemen keuangan UMKM yang didalamnya ad akas masuk, kas keluar bahkan persediaan barang samapi pengeluaran barang. Tetapi kalau melihat sistem keuangan yang digunakan sungguh sangat ribet bahkan pusing. Sehingga kami kadang masih menggunakan 
pencatatan manual agar tidak adanya kerugian dan laba yang kami tidak dapat.

Tetapi dari semua kecamatan yang dilakukannya penelitian. Terdapat di Kecamatan Paguyaman Pantai, melihat kondisi UMKM dalam penggunaan model manajemen keuangan UMKM berbasis digital, mengatakan bahwa :

\section{Persoalan di UMKM kami sangat sulit. Apalagi kalau hanya mencatat pemasukan dan pengeluaran dengan menggunakan aplikasi atau sejenisnya. Kami hanya mengandalkan kertas atau catatan seperti buku. Agar tidak membuat pusing. Yang penting bisa tahu keuntungan dan ruginya berapa.}

Dari hasil penelitian dalam model manajemen keuangan pada UMKM berbasis digital membuktikan bahwa belum sepenuhnya UMKM pada Kabupaten Boalemo mengusai model manajemen keuangan yang dijalankan. Bahkan terdapat beberapa UMKM di Kabupaten Boalemo hanya mengandalkan pencatatan manual. Bahkan ada yang sudah menggunakan aplikasi tapi mengandalkan pencatatan.

\section{PEMBAHASAN}

Berdasarkan hasil penelitian menunjukkan beberapa persepsi yang hampir berbeda dalam literasi dan model manajemen keuangan berbasis digital pada UMKMUMKM di Kabupaten Boalemo. Pada pembahasan ini akan dipaparkan beberapa hal sebagai berikut :

Literasi Keuangan UMKM di Kabupaten Boalemo

Berdasarkan hasil analisis pada pembahasan sebelumnya dapat dijelaskan bahwa literasi keuangan menjadi sesuatu yang diperlukan oleh setiap orang agar mampu menerapkan skala prioritas dalam mengelola keuangannya. Selain itu, para pebisnis juga harus mengetahui hal tersebut. Karena dengan literasi keuangan yang baik, mereka akan mampu mengelola kondisi keuangan bisnisnya dengan baik dan benar.

Padahal secara pandangan beberapa (Widayati, 2012) faktor-faktor yang mempunyai tingkat literasi keuangan status sosial ekonomi orang tua, Pendidikan pengelolaan keuangan keluarga, pembelajaran keuangan di Perguruan Tinggi (PT). Sedangkan (OJK., 2014) faktor-faktor yang mempengaruhi tingkat literasi keuangan yaitu; jenis kelamin, tingkat pendidikan, tingkat Pendapatan (Erika, 2019). Dengan hasil penelitian membuktikan bahwa hanya didominasi pada pendapatan di mana manajemen UMKM disebabkan kurang mampu bersaing dalam mengembangkan UMKM karena beberapa kesulitan seperti rata-rata pelaku UMKM di Kabupaten Boalemo terkait literasi keuangan masih belum sepenuhnya paham terutama dalam menjalankan keuangan UMKM. Baik itu dalam pencatatan, pelaporan, pengaplikasian. pembukuan dan semua hal terkait keuangan.

Seperti diketahui di beberapa kecamatan Tilamuta, Dulupi, Botumoito, Paguyaman dan Wonosari bahkan Paguyaman Pantai memang pada UMKM-UMKM yang ada mereka sudah sadar akan kemampuan dan manfaat literasi keuangan dimana UMKM dapat memanfaatkan kestabilan keuangan di tengah pandemi. Tetapi belum sepenuhnya UMKM di Kabupaten Boalemo bisa menggunakan hampir disebabkan karena belum paham dalam pengembangan UMKM berbasis digital terutama dalam menghasilkan pendapatan, bahkan tingkat pendidikan mereka dalam mengelola manajemen keuangan yang baik serta secara digital masih mengandalkan pencatatan secara manual.

Berbicara literasi dalam proses keuangan pada UMKM di Kabupaten Boalemo ternyata tingkat terhadap literasi individu sebelumnya telah dihitung berdasarkan 
keadaan saat ini pada UMKM di Kabupaten Boalemo yang telah dijelaskan sebelumnya hanya bisa digunakan sebagai dasar dalam pengambilan keputusan untuk mengkategorikan tingkat literasi individu pada beberapa UMKM di Kabupaten Boalemo. Keputusan pengkategorian tingkat literasi individu merujuk kepada yang menyatakan bahwa ada tiga kategori literasi individu, literasi rendah, literasi sedang, dan literasi tinggi. (Nayla, 2014)

Untuk itu, dalam berbagai penjelasan sebelumnya bahwa ternyata beberapa UMKM memiliki pandangannya sendiri terkait literasi keuangan. Padahal dengan adanya literasi keuangan akan mampy memberikan pengetahuan dan keterampilan masyarakat dalam membuat keputusan dan kebijakan yang efektif dengan memanfaatkan seluruh sumber daya keuangan yang dimilikinya. Melihat kondisi literasi keuangan pada UMKM pada UMKM di Kabupaten Boalemo hanya dapat mengukur kemampuan setiap UMKM dalam mendapatkan berbagai informasi keuangan yang didapatkannya. Sehingga memungkinkan mereka untuk belum mampu sepenuhnya mengambil keputusan terutama dalam perencanaan keuangan, akumulasi keuangan, hutang dan dana pensiunnya. Namun, indikator literasi keuangan nyatanya tidak bisa dibuat baku, karena layanan jasa keuangan biasanya mempunyai indikatornya sendiri untuk menilai kemampuan setiap nasabahnya. Tapi, contoh sederhananya bisa diperhatikan dari perspektif setiap individu pada UMKM.

Berbicara literasi keuangan pada UMKM di Kabupaten Boalemo ternyata lebih banyak menggunakan literasi individu yang banyak digunakan pada UMKM di Kabupaten Boalemo yang telah dijelaskan sebelumnya hanya bisa digunakan sebagai dasar dalam pengambilan keputusan untuk dikategorikan pada tingkat literasi individu pada beberapa UMKM di Kabupaten Boalemo. Keputusan pengkategorian tingkat literasi individu merujuk pada beberapa kategori literasi individu yaitu individu dengan literasi rendah, individu dengan literasi sedang, dan individu dengan literasi tinggi.

Pengembangan literasi keuangan untuk UMKM dengan bentuk berbasis pelaporan berbasis digital terutama dalam menghasilkan pendapatan, bahkan tingkat pendidikan mereka dalam mengelola manajemen keuangan yang baik serta secara digital masih mengandalkan pencatatan secara manual. Bahkan hal ini diperkuat penelitian (Kurniawan, 2021) bahwa dengan adanya lkiterasi keuangan pada UMKM tidak semuanya mengerti tentang keuangan secara keseluruhan.

Manajemen Keuangan UMKM Berbasis Digital di Kabupaten Boalemo

Dalam pelaksanaan pengembangan kapasitas manajemen keuangan UMKM peneliti bekerjasama dengan beberapa UMKM di Kabupaten Boalemo dalam melakukan penelitian serta lembaga keuangan, lembaga modal layanan mikro serta masih banyak lagi. Bahkan keterlibatan pemerintah melalui Dinas Koperasi, UMKM, Perdagangangan dan Perindustrian Kabupaten Boalemo membuat pernyataan bahwa model atau sistem manajemen keuangan terencana diperlukan informasi dan pengelolaan untuk perencanaan Aliran Dana Masuk, perencanaan Aliran Dana Keluar, perencanaan Struktur Modal dan perencanaan Investasi. Kondisi yang dialami pada UMKM saat ini bukaan hanya dalam mencari model manajemen keuangan UMKM yang baik dalam pelaksanaan, pelaporan, bahkan sampai pengaplikasiannya tetapi lebih banyak mengarah pada kemampuan UMKM dalam mengelola keuangan secara terpadu atau secara digital dalam membatu keuangan UMKM sendiri. Secara sederhana seperti pendapat (Kurniawan, 2021) mengatakan bahwa Ddsain pelatihan manajemen keuangan perlu disesuaikan berdasarkan analisa ke butuhan yang mencakup pengelolaan keuangan, 
pembiayaan/pemodalan, entrepreneur / kewirausahaan, dan menggunakan prinsipprinsip manajemen perencanaan, pelaksanaan dan evaluasi. Seperti pada gambar dibawah ini bahwa

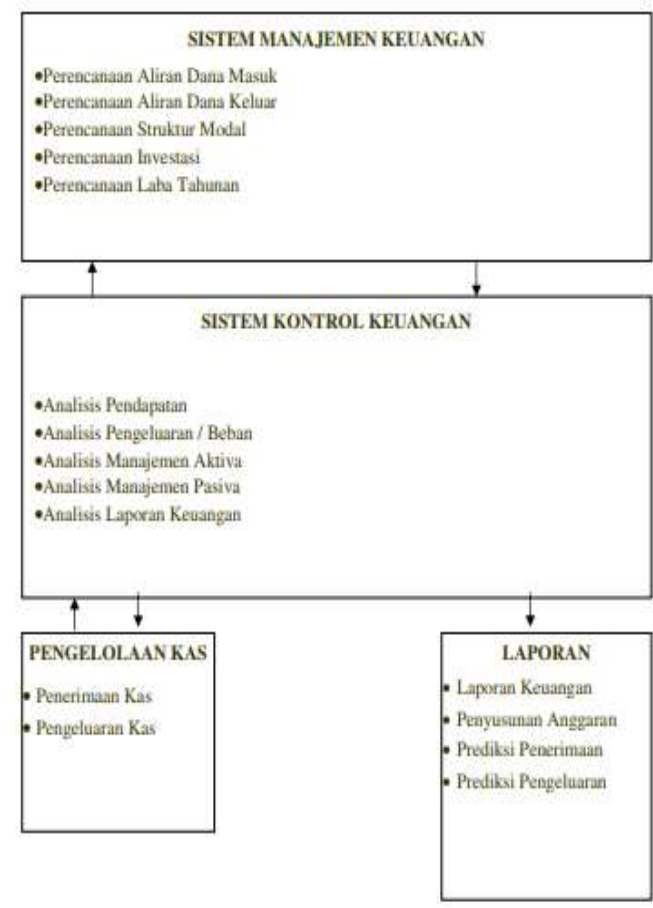

Gambar 1. Model Sistem Manajemen Keuangan Terencana

Tetapi ternyata hal ini tidak sesuai ekspetasi pada UMKM yang ada di Kabupaten Boalemo hal ini mendasari bahwa hampir semua UMKM di Kabupaten Boalemo belum mampu menggunakan model manajemen keuangan UMKM berbasis digital seperti diatas. Bahkan kemampuan UMKM dalam mengelola UMKM terutama manajemen keuangan berbasis digital masih sangat kurang. Seperti diketahui belum adanya SDM atau pengelolanya yang matang dalam menjalankan seperti itu. Kemudian masalah dalam menjalankan usahanya terutama pada masa pandemi disebabkan karena kurangnya perhatian pemerintah dalam membantu UMKM yang ada di Kabupaten Boalemo. Selain itu rata-rata Usaha Mikro, Usaha Menengah Keatas masih bisa bertahan ditengah pandemi disebabkan karena kemampuan literasi dalam model manajemen keuangan masih menggunakan cara lama dalam mempertahankan kebutuhan pengeluaran UMKM.

Bahkan terdapat beberapa UMKM dengan model manajemen keuangan yang berbasis digital belum sesuai dengan target dan tujuan. Terbukti dari beberapa pelaku atau pemilik usaha UMKM belum mampu membuat laporan keuangan secara baik, bahkan belum paham dalam pencatatan pelaporan keuangan serta pengelolaan usaha Bahkan ditemui masih banyak pelaku UMKM di Kabupaten Boalemo belum mampu menggunakan teknologi informasi dan media sosial dalam mendesain model manajemen keuangan yang ada, terutama untuk meningkatkan pasaran produk UMKM, memperluas pasar serta menghadapi persaingan. Pencatatan keuangan yang sistematis sangat bermanfaat bagi pelaku usaha kecil di Kabupaten Boalemo, manfaat-manfaat tersebut mencakupi: mampu memberikan informasi kas dengan baik sehingga kondisi keuangan usaha kecil dapat dipercaya, dengan kondisi keuangan yang baik pelaku usaha kecil mampu memberikan informasi keuangan mengenai hasil usaha dalam satu periode akuntansi, mampu memberikan informasi- informasi kepada pihak ketiga untuk menilai kondisi dan potensi suatu usaha serta mampu memberikan informasi penting lainnya yang relevan dengan pihak yang berkepentingan lainnya. (Widiastuti, 2017) Pengelolaan keuangan yang kurang baik disebabkan pemahaman dasar keuangan, memang UMKM di Kabupaten Boalemo menggunakan aplikasi excel dan aplikasi kas tetapi implemntasi bagi keuangan UMKM memang belum dimaksimalkan. Bahkan meskipun ada UMKM sudah menggunakan pencatatan, pelaporan keuangan dengan model manajemen keuangan UMKM yang berbasis digital. Tetapi karena ketakutan pelaku UMKM adalah kesalahan pencatatan dan pelaporan keuangan UMKM sehingga membuat rata- 
rata UMKM masih menggunakan pencatatan manual. Kesulitan seperti ini yang kadang menganggap para pelaku UMKM di Kabupaten Boalemo hanya berpikir secara sederhana yaitu mencari keuntungan saja.

\section{KESIMPULAN DAN SARAN}

Penelitian menjelaskan secara kualitatif bahwa UMKM di Kabupaten Boalemo mengalami berbagai masalah dalam menjalankan usahanya terutama pada masa pandemi disebabkan karena kurangnya perhatian pemerintah dalam membantu UMKM yang ada di Kabupaten Boalemo. Rata-rata UMKM di Kabupaten Boalemo dalam penggunaan literasi keuangan belum sepenuhnya paham dalam pengembangan UMKM terutama dalam meningkatkan pendapatan, bahkan tingkat pendidikan mereka dalam mengelola manajemen keuangan yang baik serta secara digital masih mengandalkan pencatatan secara manual. Sedangkan model manajemen keuangan UMKM berbasis digital belum sesuai dengan target dan tujuan. Hal ini dibuktikan pelaku usaha UMKM belum mampu membuat laporan keuangan terutama dalam pelaporan, pencatatan, pengaplikasian dan pertanggungjawaban. UMKM di Kabupaten Boalemo belum mampu menggunakan teknologi informasi dan media sosial terutama dalam memanfaatkan desain model manajemen keuangan yang berbasis digital. Disebabkan para pelaku UMKM masih mengandalkan pencatatan secara manual. Adapaun saran penelitian adalah diharapakan pemerintah daerah melalui pemerintah Kabupaten Boalemo sampai pada tingkat bawah, bahkan lembaga keuangan, non keuangan serta UMKM sendiri harus mampu lebih mengoptimalkan literasi dan model manajemen keuangan berbasis digital pada UMKM yang ada di Kabupaten Boalemo. Sehingga kedepan UMKM dapat berkembangan dan mampu bersaiang terutama dalam era digital saat ini.

\section{UCAPAN TERIMAKASIH}

Ucapan terima kasih kepada Kementerian Pendidikan Kebudayaan dan Ristek atas dana hibah penelitian 2021 dalam dukungan penyelesaian penelitian. Serta ucapan terima kasih kepada para unsur Pimpinan Universitas Bina Mandiri Gorontalo atas bantuan penyelesaian penelitian.

\section{DAFTAR PUSTAKA}

Aribawa. (2016). Pengaruh Literasi Keuangan Terhadap Kinerja dan Keberlangsungan UMKM Di Jawa Tengah. E-Jurnal UAJY, 1(20), 1-13. https://doi.org/https://doi.org/10.2088 5/jsb.vol20.iss1.art1

BAPPENAS. (2017). Metadata Indikator Tujuan Pembangunan. Berkelanjutan (TPB)/Sustainabel Development Goals (SDGs) Indonesia.

Erika, V. (2019). Pengaruh Literasi Keuangan Terhadap Pengelolaan Keuangan Mahasiswa Prodi Manajemen Fakultas Ekonomi Dan Bisnis Umsu Skripsi. Fakultas Ekonomi Dan Bisnis Universitas Muhammadiyah Sumatera Utara Medan.

Hermann, M., Pentek, T., \& Otto, B. (2016). Design Principles for Industrie 4.0 Scenarios.

Kasmir. (2012). Analisis Laporan Keuangan. Raja Grafindo.

Kurniawan, R. I. O. (2021). Literasi keuangan masyarakat penerima program umkm dan blt di lingkungan cerbonan kabupaten karanganyar.

Mulyawan. (2015). Manajemen Keuangan. CV PUSTAKA SETIA.

Nayla, A. (2014). Komplet Akuntansi untuk UKM dan Waralaba. Laksana.

OJK. (2014). Strategi Nasional Literasi Keuangan Indonesia. In Direktorat Literasi dan Edukasi.

OJK. (2016). Keuangan Nomor 76 /POJK.07/2016 Peraturan Otoritas Jasa Keuangan Nomor 76 /POJK.07/2016 Tentang Peningkatan 
Literasi dan Inklusi Keuangan di Sektor Jasa Keuangan Bagi

Konsumen dan/atau Masyarakat.

Ridhotullah, S. dan M. J. (2015).

Pengantar Manajemen (Prestasi P).

Shaari, et al. (2013). Financial Literacy :

A Study Among The University

Students. Interdisciplinary Journal of

Cotemporary Research in Business., $5(2)$.

Sugiyono. (2018). Metode Penelitian

Kuantitatif. Alfabeta.

Sujarweni, W. (2014). Metodologi

Penelitian. Pustaka Baru. Press.

Sukmadinata. (2011). Metode Penelitian

Pendidikan. PT Remaja Rosdakarya.

Wicaksono, D. (2015). Teori

Pembelajaran Bahasa (Suatu Catatan

Singkat). Garudawacha.

Widayati, I. (2012). Faktor-Faktor Yang

Mempengaruhi Literasi Finansial

Mahasiswa Fakultas Ekonomi Dan

Bisnis Universitas Brawijaya. Jurnal

Akuntansi Dan Pendidikan, 1(1).

Widiastuti, C. T. (2017). MODEL

MANAJEMEN EDU-FINANCE

UNTUK MENINGKATKAN

LITERASI KEUANGAN PADA

UMKM KAYU KOTA

SEMARANG. Jurnal Bisnis Dan

Ekonomi (JBE), 24(2), 112-118. 